\title{
Structural Racism, Whiteness, and the African Studies Review - CORRIGENDUM
}

https://doi.org/10.1017/asr.2020.84, published by Cambridge University Press, 7 October 2020

In the editorial to African Studies Review issue 63 (3), we incorrectly identified all but one of the previous editors as white Americans. This is incorrect. For the period 1975 to 1980 , Alan K. Smith (Syracuse University) served as Editor, with Evelyn Jones Rich as Associate Editor. Both individuals are African American.

The editors apologize for this error and the offense it caused.

\section{Reference}

African Studies Review Editorial Collective. 2020. "Structural Racism, Whiteness, and the African Studies Review." African Studies Review 63 (3): 443-448.

African Studies Review, Volume 63, Number 4 (December 2020), pp. 938

(C) The Author(s), 2020. Published by Cambridge University Press on behalf of the African Studies Association 